\title{
Oxidative stress increases placental and endothelial cell activin A secretion
}

\author{
Stephen Mandang, Ursula Manuelpillai and Euan M Wallace \\ Department of Obstetrics and Gynaecology, Monash Institute for Medical Research, Monash Medical Centre, Monash University, 246 Clayton Road, Clayton, \\ Victoria 3168, Australia \\ (Requests for offprints should be addressed to E M Wallace; Email: euan.wallace@med.monash.edu.au)
}

\begin{abstract}
Circulating levels of activin A are significantly increased in women with preeclampsia when compared with those with a normal pregnancy. The mechanisms underlying these increased levels are unknown. We undertook these studies to explore whether oxidative stress might be the mechanism. We exposed trophoblast explants, human umbilical vein endothelial cells (HUVECs) and peripheral blood monocytes to oxidative stress in vitro using xanthine/xanthine oxidase $(\mathrm{X} / \mathrm{XO})$, measuring activin $\mathrm{A}$ and isoprostane in conditioned media and mRNA for activin $\beta_{\mathrm{A}}$ in explants and HUVECs. We also measured isoprostane and activin $\mathrm{A}$ in serum from 21 women with preeclampsia and from 20 women with a normal pregnancy. Treatment with $\mathrm{X} / \mathrm{XO}$ significantly increased 8-isoprostane production from placental explants, HUVECs and monocytes, indicative of oxidative stress, and significantly increased activin A output from placental
\end{abstract}

explants $(139 \cdot 1 \pm 27 \cdot 4$ per $\mathrm{mg}$ wet weight vs $322 \cdot 9 \pm$ $89.7 \mathrm{pg} / \mathrm{ml}$ per mg wet weight, $P=0.02)$ and from HUVECs $(1 \cdot 2 \pm 0 \cdot 2$ vs $3 \cdot 2 \pm 1 \cdot 8 \mathrm{ng} / \mathrm{ml}, P=0 \cdot 04)$. There was no effect on activin $\mathrm{A}$ output from monocytes. $\mathrm{X} / \mathrm{XO}$ significantly increased $\beta_{\mathrm{A}}$ mRNA in placental explants but not in HUVECs. Maternal plasma levels of 8-isoprostane and activin A were significantly higher in women with preeclampsia when compared with controls $(333 \cdot 8 \pm 70$ vs $176 \cdot 3 \pm$ $26 \cdot 2 \mathrm{pg} / \mathrm{ml}, P=0.04$ and $49 \cdot 5 \pm 7$ vs $13 \cdot 1 \pm 1 \cdot 2 \mathrm{ng} / \mathrm{ml}$, $P<0 \cdot 001$ respectively). In the women with preeclampsia, but not in those with a normal pregnancy, circulating levels of 8 -isoprostane and activin A were significantly and positively correlated $\left(r^{2}=0 \cdot 72 ; P<0 \cdot 001\right)$. These data suggest that oxidative stress may be one of the mechanisms underlying increased circulating activin A in preeclampsia.

Journal of Endocrinology (2007) 192, 485-493

\section{Introduction}

Activins are dimeric glycoprotein members of the transforming growth factor $\beta$ (TGF- $\beta$ ) superfamily (Massague 1990). In pregnancy, the placenta is the major source of activin in the maternal circulation (de Kretser et al. 1994, Qu \& Thomas 1995, Wallace \& Healy 1996, Fowler et al. 1998), secreting predominantly activin A (Fowler et al. 1998). Maternal serum levels of activin A increase from about mid-pregnancy to a peak close to term (Muttukrishna et al. 1996, Fowler et al. 1998, Schneider-Kolsky et al. 2002), falling quickly after birth (Fowler et al. 1998). In pregnancies complicated by placental dysfunction as evidenced by intrauterine foetal growth restriction (Bobrow et al. 2002, Wallace et al. 2003, Barkehall-Thomas et al. 2006) or preeclampsia (Muttukrishna et al. 1997, D'Antona et al. 2000, Manuelpillai et al. 2001, Silver et al. 2002), maternal serum levels of activin A are significantly higher than observed in normal pregnancy. While these increased circulating levels of activin A are thought to arise from increased placental production (Manuelpillai et al. 2001, Silver et al. 2002) the mechanism(s) underlying such increased placental output remain unclear.
On the basis of histological (Brosens \& Renaer 1972) and, more recently, molecular (Soleymanlou et al. 2005) evidence of placental hypoxia in preeclampsia and on the in vivo observations in sheep that both acute (Jenkin et al. 2001) and chronic (Supramaniam et al. 2006) foetoplacental hypoxia increases amniotic fluid levels of activin $\mathrm{A}$, hypoxia has been explored as a possible cause of increased placental activin production in vitro (Blumenstein et al. 2002, Manuelpillai et al. 2003). However, in contrast to the in vivo ovine data, in vitro culture of first trimester and term human placental explants under low oxygen conditions consistently reduced activin A production (Blumenstein et al. 2002, Manuelpillai et al. 2003), suggesting that placental hypoxia is not a likely cause of the increased activin A observed in preeclampsia.

In preeclampsia, while hypoxic (Soleymanlou et al. 2005) the placenta also displays evidence of excessive oxidative stress (Hubel 1999, Burton \& Jauniaux 2004, Myatt \& Cui 2004), thought to result from either hypoxia-reperfusion injury (Burton \& Hung 2003) and/or deficient antioxidant defences (Perkins 2006). In turn, increased placental oxidative stress has been linked to the systemic features of preeclampsia (Roberts \& Hubel 1999) through the release of a variety of possible 
mediators of endothelial cell dysfunction such as lipid peroxides (Walsh 1998), pro-inflammatory cytokines (Hung et al. 2004, Matthiesen et al. 2005) and syncytiotrophoblast microparticles (Redman \& Sargent 2000). Accordingly, we undertook this study to explore whether oxidative stress may be the mechanism underlying increased placental activin A production in preeclampsia and to explore whether circulating levels of activin were correlated with circulating levels of a marker of systemic oxidative stress. Furthermore, since it has been suggested that endothelial cells (Manuelpillai et al. 2001, Tannetta et al. 2003) and leucocytes (Tannetta et al. 2003) may also contribute to circulating levels of activin A, we explored the effect of oxidative stress on activin output from these sources.

\section{Materials and Methods}

\section{Sample collection}

Maternal blood was collected from the antecubital vein of women with a singleton pregnancy in the absence of labour. Samples were collected from 21 women between 26 and 40 weeks of pregnancy with established preeclampsia, as defined by Australian Society for the Study of Hypertension in Pregnancy (Brown et al. 2000), medicated with oral labetalol and/or nifedipine and from 20 women with a gestation-matched healthy pregnancy. Blood was centrifuged at $2000 \boldsymbol{g}$ for $10 \mathrm{~min}$ at room temperature for serum collection and at $4{ }^{\circ} \mathrm{C}$ for plasma. Serum was stored at $-20{ }^{\circ} \mathrm{C}$ prior to analysis. To prevent oxygen free radical formation $0.005 \%$ butylated hydroxytoluene (BHT, Sigma) was added to plasma samples prior to storage at $-80{ }^{\circ} \mathrm{C}$.

Placental tissue $(n=11)$, umbilical cords $(n=6)$ and maternal peripheral blood $(n=6)$ for explant and cell isolation were obtained from women with a healthy, singleton pregnancy undergoing an elective caesarean section at term (37-40 weeks gestation) for either breech presentation or previous caesarean section.

All women participating in the study gave informed written consent. The study was approved by the Southern Health Human Research and Ethics Committee.

\section{Placental explant culture}

Explants $(35-50 \mathrm{mg}$ ) from terminal regions of chorionic villi were coated in the ratio of 1:3 dilution (v/v) Matrigel (BD Biosciences, Franklin Lakes, NJ, USA) and placed in six-well culture dishes (BD Biosciences). Each well contained approximately $150 \mathrm{mg}$ tissue. Explants were cultured in serum free DMEM/F12 (Gibco-BRL) at $37{ }^{\circ} \mathrm{C}$ in $5 \% \mathrm{CO}_{2}$ and $95 \%$ air for $48 \mathrm{~h}$ before treatment, as previously described (Manuelpillai et al. 2003). Explants were then treated with $2.3 \mathrm{mM}$ xanthine $(\mathrm{X})$ and $0.015 \mathrm{U} / \mathrm{ml}$ xanthine oxidase (XO) (Sigma), as previously described by others (Malek et al. 2001) for a further 24 and $48 \mathrm{~h}$. Untreated cultures served as controls. For antioxidant treatment, cells were incubated with $\mathrm{X} / \mathrm{XO}$ (as above) for $24 \mathrm{~h}$ and then treated with $\mathrm{X} / \mathrm{XO}$ and
$100 \mathrm{U} / \mathrm{ml}$ superoxide dismutase (SOD; Khullar et al. 2004) or $50 \mu \mathrm{M}$ vitamin $\mathrm{C}$ and $25 \mu \mathrm{M}$ vitamin $\mathrm{E}$ (Milczarek et al. 2000) for a further $24 \mathrm{~h}$ before media collection and RNA isolation. Conditioned media were collected and stored at $-20{ }^{\circ} \mathrm{C}$ for activin $\mathrm{A}$ and 8 -isoprostane analysis. Explants were snap frozen and stored at $-80{ }^{\circ} \mathrm{C}$ for RNA extraction.

\section{Human umbilical vein endothelial cells (HUVECs) isolation and culture}

HUVECs were isolated as previously described (Jaffe et al. 1973). Cells were cultured in M199 medium (Gibco-BRL) with $20 \%$ heat-inactivated FCS, epidermal and fibroblast growth factors $(10 \mathrm{ng} / \mathrm{ml}$ each), heparin $(90 \mu \mathrm{g} / \mathrm{ml})$, penicillin $\mathrm{G}(100 \mathrm{U} / \mathrm{ml})$, streptomycin sulphate $(100 \mu \mathrm{g} / \mathrm{ml})$ and amphotericin B $(0 \cdot 25 \mu \mathrm{g} / \mathrm{ml}$; Invitrogen). HUVECs were seeded into flasks coated with $0 \cdot 2 \%$ gelatin (Sigma-Aldrich). Cells were expanded and cultures used for experiments were taken from second or third passages.

Cells were seeded in $24-w e l l$ plates $\left(5 \times 10^{4}\right.$ cells/well $)$ coated with gelatin and maintained in culture for $48 \mathrm{~h}$ prior to treatment. To induce oxidative stress, media were supplemented with $50 \mu \mathrm{M} \mathrm{X}$ and $0.8 \mathrm{mU} / \mathrm{ml} \mathrm{XO}$ (Sigma) and conditioned media collected and stored at $-20{ }^{\circ} \mathrm{C}$ after 24 and $48 \mathrm{~h}$ for subsequent activin $\mathrm{A}$ and 8 -isoprostane analysis. The doses of $\mathrm{X} / \mathrm{XO}$ were based upon dose-response studies utilising 8 -isoprostane as an outcome (data not shown). The antioxidant treatment was as described above before media collection and RNA isolation.

\section{Monocyte isolation and culture}

Monocytes were isolated from peripheral blood mononuclear cells (PBMCs) after Ficoll-Paque Plus (Amersham Biosciences) density configuration, using magnetic cell sorting (MACS), (Miltenyi Biotec, Gladbach, Germany) as previously described (Hafsi et al. 2004). Cells $\left(2 \times 10^{6}\right.$ cells $\left./ \mathrm{ml}\right)$ were plated in $24-w e l l$ plates and cultured in RPMI 1640 supplemented with antibiotics, $10 \% \mathrm{FCS}, 50 \mu \mathrm{M} \mathrm{X}$ and $0.8 \mathrm{mU} / \mathrm{ml} \mathrm{XO}$ for $24 \mathrm{~h}$. The antioxidant treatment was as described above. Conditioned media were collected after 24 and $48 \mathrm{~h}$ and stored at $-20{ }^{\circ} \mathrm{C}$ for activin $\mathrm{A}$ and 8 -isoprostane analysis.

\section{Quantitative real-time PCR}

Total RNA was isolated from placental explants and HUVECs using Trizol reagent (Invitrogen) and cell to signal lysis buffer (Ambion, Austin, TX, USA) respectively. Two and a half micrograms of total placental RNA and $12 \mu \mathrm{l}$ HUVEC lysate were reverse transcripted into cDNA (cDNA) using random primers and Superscript III (Invitrogen). Placental cDNA was diluted in the ratio of 1:100. Five microlitres of cDNA were mixed with primers specific for human activin $\beta A$ (that spanned intron-exon junctions), SYBR Green reaction mix (Roche Diagnostics) and subjected to quantitative real-time PCR (q-PCR, Rotor Gene RG-3000, Corbett Research, Sydney, 
Australia). The forward and reverse activin A primers were $5^{\prime}$ GGA GGG CAG AAA TGA ATG AA $3^{\prime} ; 5^{\prime}$ CTG CTG GAG ACA GGG AAG AC $3^{\prime}$ respectively. The cycling parameters were: denaturation $95^{\circ} \mathrm{C}$ for $10 \mathrm{~s}$, annealing $59^{\circ} \mathrm{C}$ for $13 \mathrm{~s}$ and extension $72{ }^{\circ} \mathrm{C}$ for $15 \mathrm{~s}$. Using these parameters, a single peak melt curve for activin $\beta$ A was obtained with a melt temperature of $90{ }^{\circ} \mathrm{C}$. Agarose gel electrophoresis was performed to check the size of the amplicon generated, confirming it to be $350 \mathrm{bp}$ consistent with its predicted size, and the product verified as activin $\beta$ A by DNA sequencing. For normalisation, $2 \mu \mathrm{cDNA}$ were amplified to detect $18 \mathrm{~S}$ rRNA alongside the target cDNA. Forward and reverse $18 \mathrm{~S}$ primers were $5^{\prime} \mathrm{CGG}$ CTA CCA CAT CCA AGG AA 3'; 5' GCT GGA ATT ACC GCG GCT 3' respectively. The primers used to amplify $18 \mathrm{~S}$ rRNA gave a single peak melt curve with a melt temperature of $87^{\circ} \mathrm{C}$. The amplicon generated was $180 \mathrm{bp}$ in length and its sequence was also verified. Negative controls reactions for $\beta A$ and $18 \mathrm{~S}$ lacked melt curves. The amplification efficiencies for activin $\beta A$ and $18 \mathrm{~S}$ were 1.04 and 1.02 respectively, determined using Corbett Instruments Rotorgene software. Standard curves for activin A and $18 \mathrm{~S}$ were prepared from term placental cDNA and the cDNA concentrations relative to $18 \mathrm{~S}$ was determined using Rotor Gene version 6.0 software (Corbett Research). For each test sample, the concentration of $\beta A$, determined using the Rotorgene software, was divided by the concentration of $18 \mathrm{~S}$ for purposes of normalisation. For each sample, analyses were carried out in duplicate and averaged.

\section{Activin A ELISA}

Total activin A in maternal serum and conditioned media was measured using a commercial two-site enzyme-linked immunosorbant assay (DSL, Webster, TX, USA), with minor modifications as described previously (Riley et al. 1998). Maternal serum and placental explant conditioned media were diluted in the ratio of $1: 10$ and 1:3 with assay diluent respectively, whereas cell conditioned media was assayed undiluted. The sensitivity of the assay was $72 \mathrm{pg} / \mathrm{ml}$ and the mean intra- and inter-assay coefficients of variation were 8 and $15 \%$ respectively.

\section{8-Isoprostane EIA}

8-Isoprostane in maternal plasma and conditioned media was measured using a commercial enzyme immunoassay (Cayman Chemical, Ann Arbor, MI, USA) according to the manufacturer's instructions. Plasma was assayed undiluted, whereas placental explant and cell conditioned media were diluted in the ratio of $1: 100$ and 1:5 respectively. The intraand inter-assay coefficients of variation were $7 \cdot 2$ and $18.5 \%$ respectively. The sensitivity of the assay was $5 \mathrm{pg} / \mathrm{ml}$.

\section{Statistical analysis}

All the data are expressed as means \pm S.E.M. Differences in maternal serum levels of activin A and 8 -isoprostane between women with preeclampsia and a normal pregnancy were analysed using unpaired $t$-test. Correlations between activin A and 8 -isoprostane in both groups were assessed by Pearson's rank correlation coefficient. The effect of $\mathrm{X} / \mathrm{XO}$ on placental explant, HUVEC and monocyte activin A secretion was assessed by paired $t$-test. Kruskal-Wallis test followed by post hoc Dunn's test for multiple comparisons were used to analyse the differences in mRNA expression and one-way ANOVA and post hoc Bonferroni's test for multiple comparisons were used to analyse the changes in placental explant and HUVEC activin A output in the presence of SOD and vitamin $\mathrm{C} / \mathrm{E}$. All statistical analyses were performed using GraphPad Prism version 4.01 (San Diego, CA, USA). In all cases significance was assumed when $P<0 \cdot 05$.

\section{Results}

\section{Activin $A$ and 8-isoprostane in maternal circulation}

The clinical characteristics of the 41 women with preeclampsia and normal pregnancy at the time of maternal blood collection are detailed in Table 1. Maternal plasma levels of 8-isoprostane were significantly higher in women with preeclampsia when compared with controls $(333 \cdot 82 \pm 70 \cdot 01$ vs $176 \cdot 32 \pm$ $26 \cdot 24 \mathrm{pg} / \mathrm{ml}, P=0 \cdot 04)$ as were maternal serum levels of activin A $(49 \cdot 46 \pm 7 \cdot 02$ vs $13 \cdot 13 \pm 1 \cdot 84 \mathrm{ng} / \mathrm{ml}, P<0 \cdot 001)$. In women with preeclampsia there was a significant positive correlation between circulating levels of 8-isoprostane and activin A (Fig. 1A, Pearson's correlation $r^{2}=0.72 ; P<0 \cdot 001$ ) but no correlation in women with a normal pregnancy (Fig. 1B, Pearson's correlation $\left.r^{2}=-0 \cdot 15 ; P=0 \cdot 17\right)$.

Effect of X/XO on 8-isoprostane, activin $A$ secretion and activin $\beta A m R N A$ expression

$\mathrm{X} / \mathrm{XO}$ treatment induced oxidative stress in placental explants, HUVECs and monocytes as shown by increased levels of 8 -isoprostane when compared with controls (Table 2).

Figure 2 summarises the effects of $\mathrm{X} / \mathrm{XO}$ on activin secretion from placental explants, HUVECs and monocytes.

Table 1 Clinical characteristics of women with preeclampsia and normal pregnancy. Data are presented as means \pm s.E.M.

\begin{tabular}{|c|c|c|c|}
\hline Maternal age (years) & $32 \cdot 4 \pm 1 \cdot 1$ & $29 \cdot 8 \pm 1 \cdot 3$ & $0 \cdot 1$ \\
\hline $\begin{array}{l}\text { Gestational age at } \\
\text { sampling (weeks) }\end{array}$ & $31 \cdot 2 \pm 0 \cdot 8$ & $33 \cdot 4 \pm 1 \cdot 0$ & $0 \cdot 1$ \\
\hline $\begin{array}{r}\text { Gestational age at } \\
\text { delivery (weeks) }\end{array}$ & $37 \cdot 2 \pm 0 \cdot 6$ & $33 \cdot 8 \pm 1 \cdot 0$ & $0 \cdot 04$ \\
\hline Primigravida (\%) & 65 & 67 & $0 \cdot 5$ \\
\hline Systolic BP (mmHg) & $109 \cdot 8 \pm 2 \cdot 1$ & $158 \cdot 2 \pm 4 \cdot 4$ & $<0 \cdot 001$ \\
\hline Diastolic BP (mmHg) & $70 \cdot 6 \pm 2 \cdot 0$ & $101 \cdot 8 \pm 2 \cdot 1$ & $<0 \cdot 001$ \\
\hline BMI $\left(\mathrm{kg} / \mathrm{m}^{2}\right)$ & $25 \cdot 2 \pm 0 \cdot 9$ & $26 \cdot 4 \pm 1 \cdot 6$ & $0 \cdot 7$ \\
\hline
\end{tabular}

$\mathrm{NP}$, normal pregnancy; $\mathrm{PE}$, preeclampsia; $\mathrm{BP}$, blood pressure; $\mathrm{BMI}$, body mass index. 

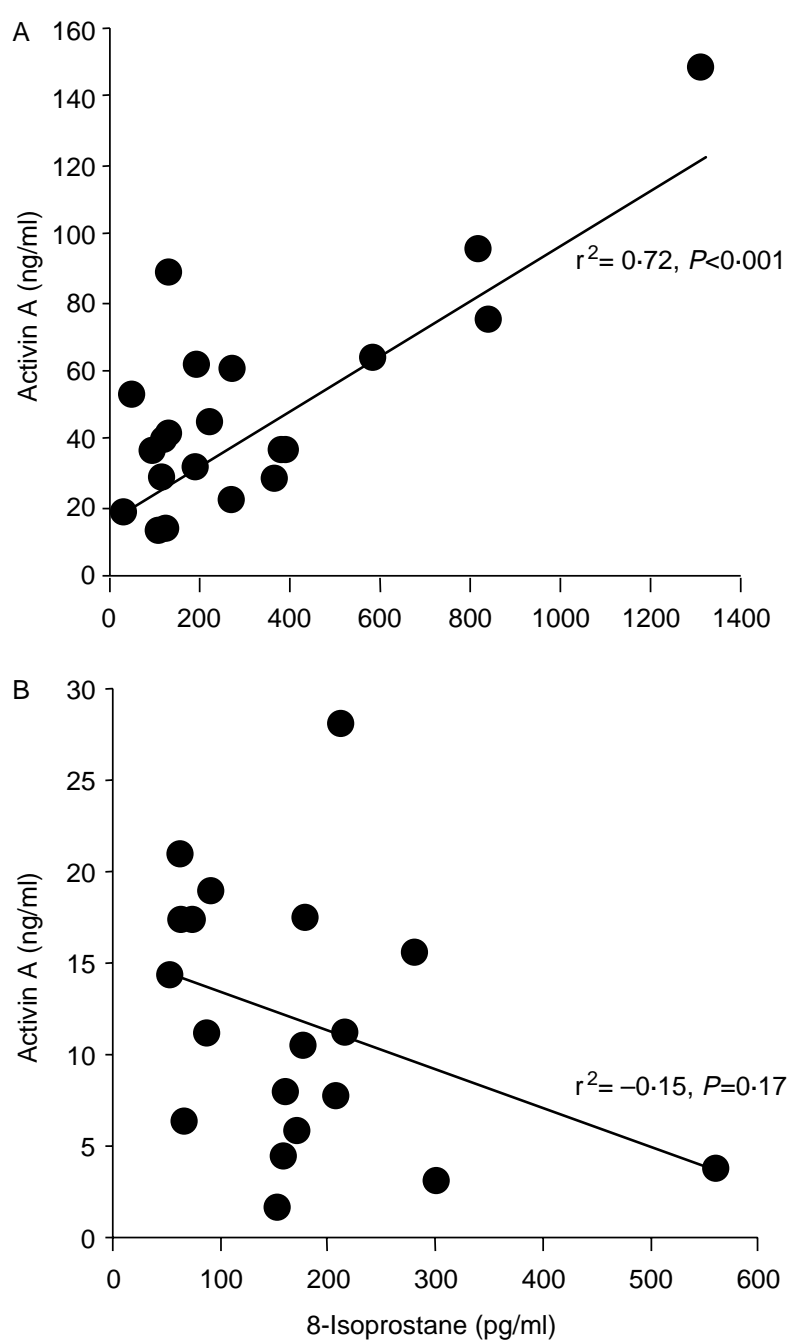

Figure 1 Correlation between circulating levels of activin A and 8isoprostane in 21 women with preeclampsia (A) and 20 women with normal pregnancy (B).

When compared with control cultures, treatment of placental explants with $\mathrm{X} / \mathrm{XO}$ significantly increased activin $\mathrm{A}$ in conditioned media (Fig. 2A: mean \pm s.E.M. activin A: 59.6 $7 \cdot 9 \mathrm{pg} / \mathrm{ml}$ per $\mathrm{mg}$ wet tissue vs $145 \cdot 1 \pm 47.9 \mathrm{pg} / \mathrm{ml} / \mathrm{mg}$ wet tissue at $24 \mathrm{~h}, P=0 \cdot 04$ and $139 \cdot 1 \pm 27 \cdot 4 \mathrm{pg} / \mathrm{ml}$ per $\mathrm{mg}$ wet tissue vs $322 \cdot 9 \pm 89.7 \mathrm{pg} / \mathrm{ml} / \mathrm{mg}$ wet tissue at $48 \mathrm{~h}, P=0 \cdot 02)$. When compared with control cultures, treatment of
HUVECs with $\mathrm{X} / \mathrm{XO}$ significantly increased activin $\mathrm{A}$ in conditioned media (Fig. 2B: mean \pm s.E.M. activin A: $1 \cdot 1 \pm$ $0 \cdot 2$ vs $2 \cdot 1 \pm 0 \cdot 2 \mathrm{ng} / \mathrm{ml}$ at $24 \mathrm{~h}, P=0 \cdot 01$ and $1 \cdot 2 \pm 0 \cdot 2$ vs $3 \cdot 2 \pm 1 \cdot 8 \mathrm{ng} / \mathrm{ml}$ at $48 \mathrm{~h}, P=0 \cdot 04)$. Basal levels of activin A in monocyte-conditioned media were very low and did not increase in the presence of $\mathrm{X} / \mathrm{XO}$ (Fig. 2C).

Consistent with the changes in activin $\mathrm{A}$ in conditioned media, treatment with $\mathrm{X} / \mathrm{XO}$ significantly increased the expression of activin $\beta \mathrm{A}$ mRNA in placental explants at $24 \mathrm{~h}$ $(P=0.03$ when compared with control; Fig. 3A). There were no significant differences in activin $\beta A$ mRNA expression in either HUVECs (Fig. 3B) or monocytes (data not shown).

Effect of antioxidants on $X / X O$ induction of 8-isoprostane, activin $A$ secretion and activin $\beta A m R N A$ expression

The addition of vitamin $\mathrm{C} / \mathrm{E}$, but not SOD, significantly mitigated $\mathrm{X} / \mathrm{XO}$-induced release of 8 -isoprostane at $24 \mathrm{~h}$ from placental explants $(P=0 \cdot 02$, Fig. $4 \mathrm{~A})$. There was no apparent effect of either vitamin $\mathrm{C} / \mathrm{E}$ or SOD on $\mathrm{X} / \mathrm{XO}-$ induced 8-isoprostane release from HUVECs (Fig. 4B).

The addition of vitamin $\mathrm{C} / \mathrm{E}$, but not SOD, significantly mitigated both $\mathrm{X} / \mathrm{XO}$-induced release of activin $\mathrm{A}$ from placental explants $(P<0 \cdot 01$, Fig. 5A) and $\mathrm{X} / \mathrm{XO}$-induced activin $\beta A$ mRNA expression in placental explants $(P<0 \cdot 04$, Fig. $3 \mathrm{~A})$ at $24 \mathrm{~h}$. The effects of vitamin $\mathrm{C} / \mathrm{E}$ and SOD treatment on $\mathrm{X} / \mathrm{XO}$-induced changes in activin $\beta \mathrm{A}$ mRNA expression and activin A secretion from HUVECs were not statistically significant $(P=0.96$ and 0.55 respectively; Figs $3 \mathrm{~B}$ and $5 \mathrm{~B})$.

\section{Discussion}

In this study, we have shown that oxidative stress, induced by $\mathrm{X} / \mathrm{XO}$, stimulates activin A production and secretion from placental explants and endothelial cells but not from peripheral blood monocytes. We have further shown that in women with preeclampsia circulating levels of activin A are significantly associated with 8 -isoprostane, a marker of lipid peroxidation and excessive systemic oxidative stress. Taken together, these new observations suggest that oxidative stress may be a mechanism underlying the increased levels of activin A present in women with preeclampsia.

Table 2 Mean \pm S.E.M. levels of 8 -isoprostane in media conditioned by placental explants ( $\mathrm{pg} / \mathrm{mg}$ wet weight tissue), HUVECs $(\mathrm{pg} / \mathrm{ml})$ and peripheral blood monocytes $(\mathrm{pg} / \mathrm{ml})$ under control conditions and in the presence of X/XO

\begin{tabular}{|c|c|c|c|c|c|c|}
\hline & \multicolumn{3}{|l|}{$24 \mathrm{~h}$} & \multicolumn{3}{|l|}{$48 \mathrm{~h}$} \\
\hline & Control & $\mathrm{X} / \mathrm{XO}$ & $P$ value & Control & $\mathrm{X} / \mathrm{XO}$ & $P$ value \\
\hline Placental explants & $11 \cdot 8 \pm 2 \cdot 9$ & $40 \cdot 9 \pm 10 \cdot 9$ & $0 \cdot 009$ & $56 \cdot 3 \pm 13 \cdot 3$ & $248 \pm 77 \cdot 4$ & $0 \cdot 01$ \\
\hline HUVECS & $119 \cdot 9 \pm 37 \cdot 4$ & $271 \cdot 4 \pm 28 \cdot 5$ & $0 \cdot 03$ & $168 \cdot 9 \pm 46 \cdot 1$ & $354 \cdot 7 \pm 41 \cdot 5$ & $0 \cdot 04$ \\
\hline Monocytes & $270 \pm 46 \cdot 8$ & $375 \cdot 2 \pm 51 \cdot 6$ & $0 \cdot 14$ & $172 \pm 53 \cdot 5$ & $306 \cdot 3 \pm 27 \cdot 7$ & $0 \cdot 04$ \\
\hline
\end{tabular}




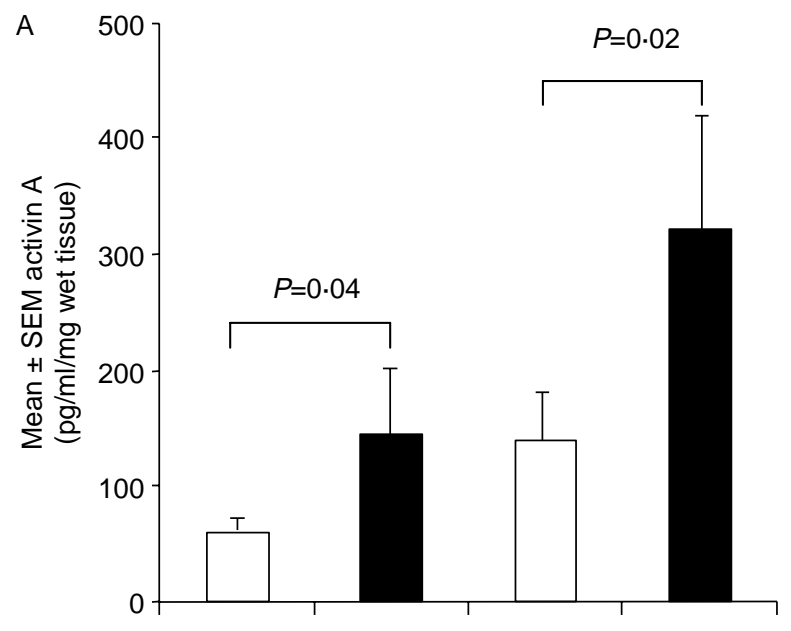

B

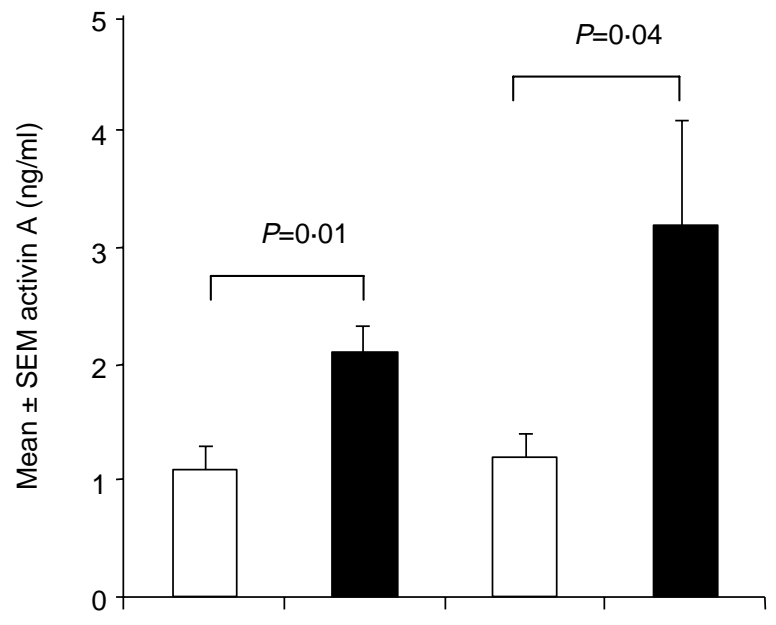

C

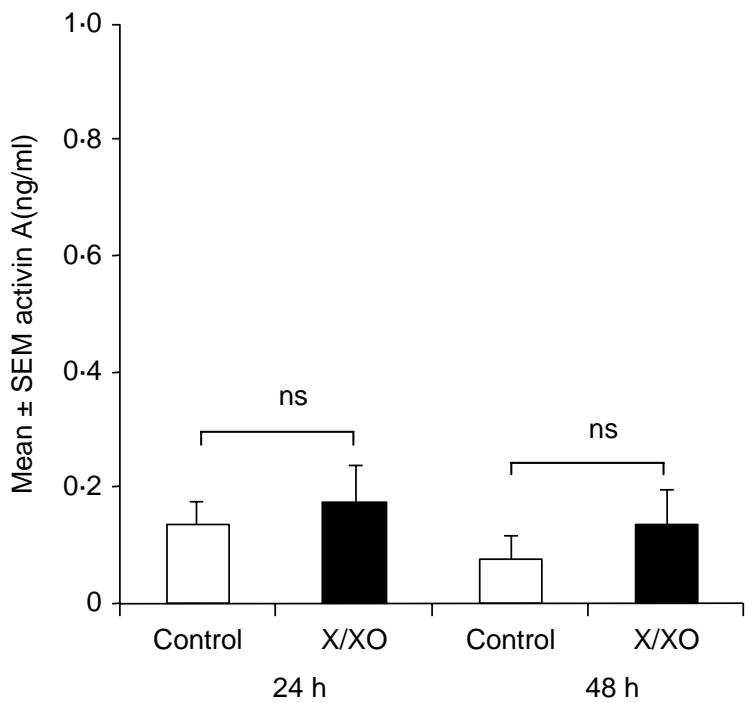

Figure 2 The effect of $X / X O$ on term placental explant (A), HUVEC (B) and monocyte $(\mathrm{C})$ secretion of activin $\mathrm{A}$ in vitro. $\mathrm{ns}$, not significant.

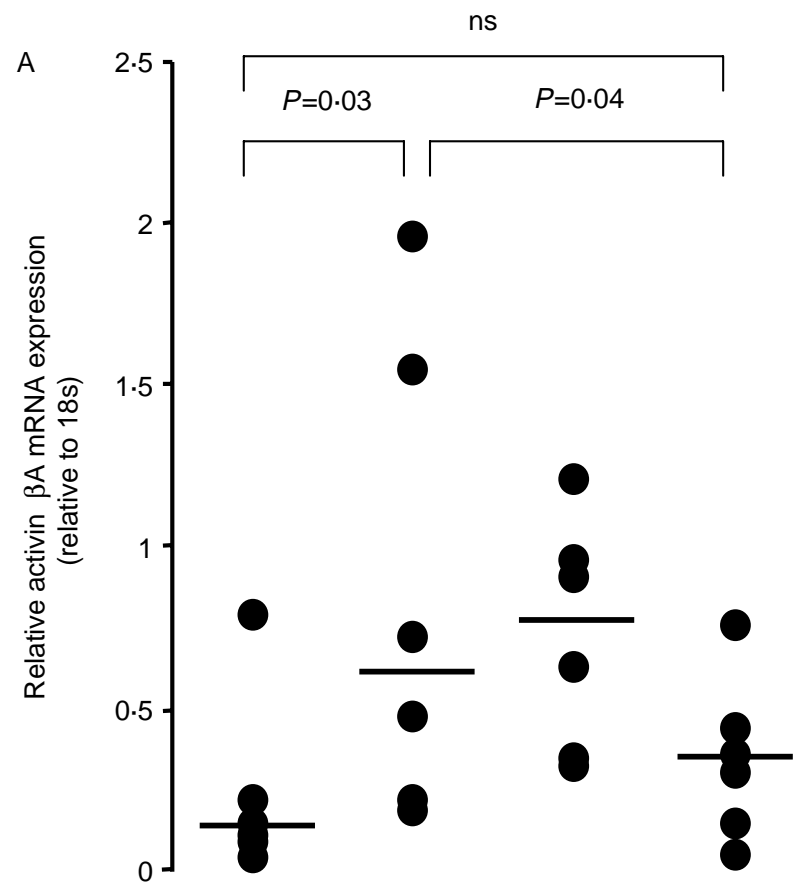

B

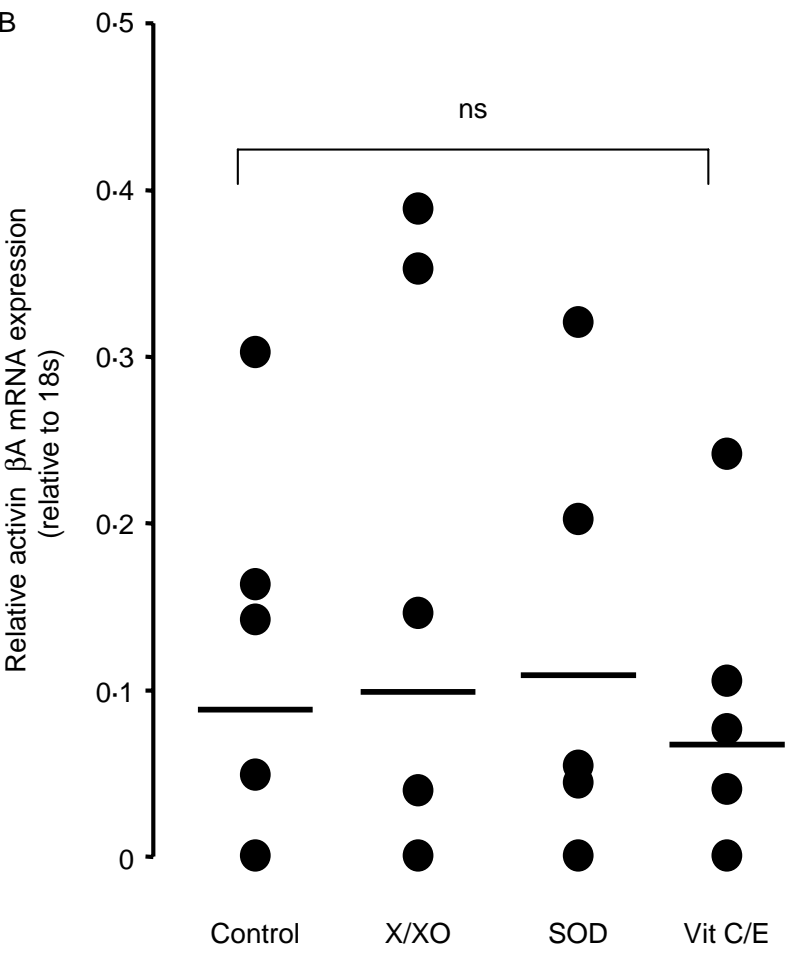

Figure 3 The effect of $\mathrm{X} / \mathrm{XO}$ and antioxidants (SOD and vitamin $\mathrm{C} / \mathrm{E}$ ) on median activin $\beta A$ mRNA expression in placental explants (A) and HUVECs (B). ns, not significant. 

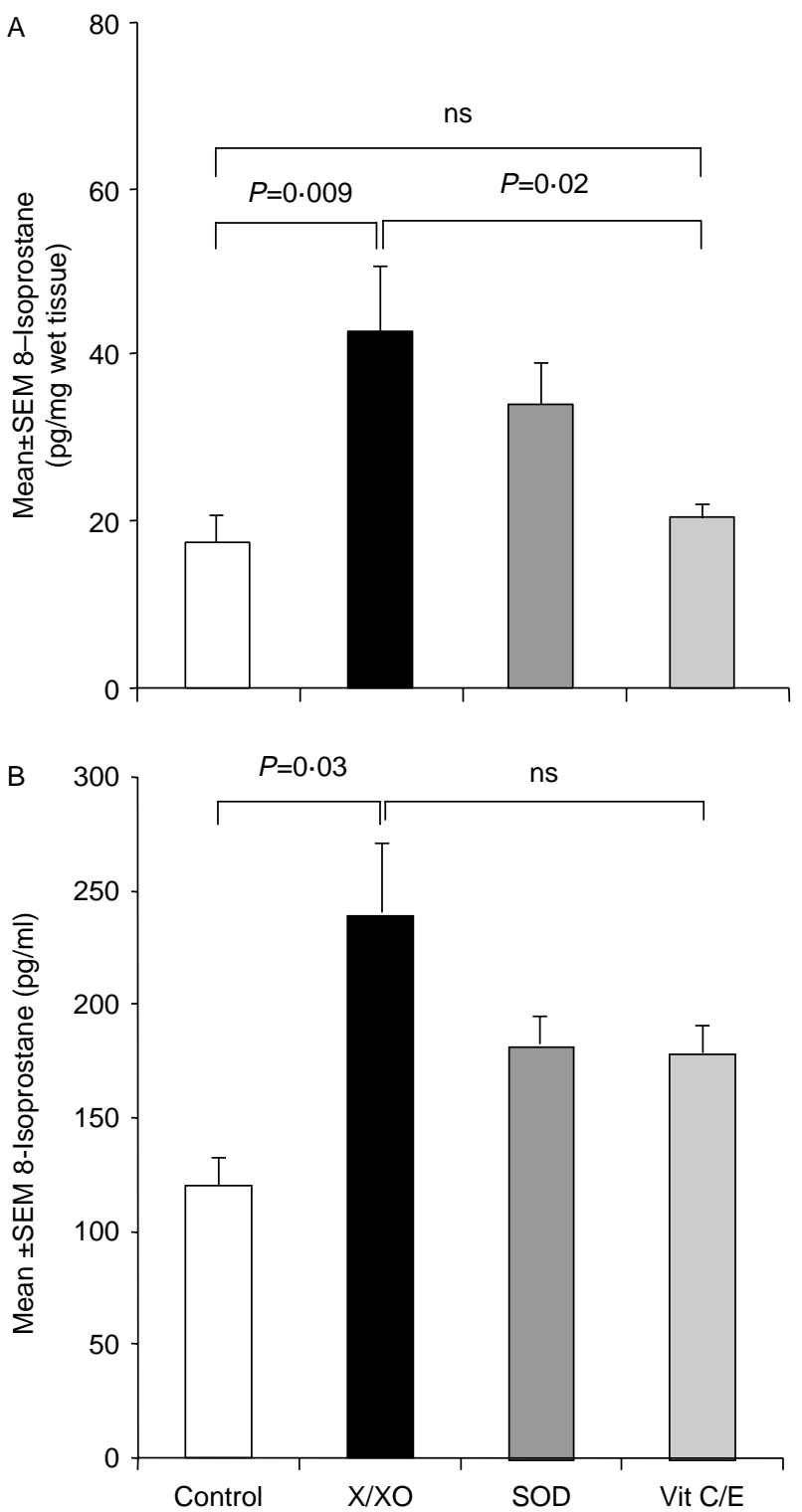

Figure 4 The effect of $X / X O$ and antioxidants (SOD and vitamin $C / E$ ) on 8-isoprostane secretion from placental explants (A) and HUVECs (B) in vitro at $24 \mathrm{~h}$. ns, not significant.

As reviewed elsewhere (Tong et al. 2003), circulating levels of activin A are greatly increased in women with preeclampsia when compared with those with a normal pregnancy. Previous studies have shown that the placental content and circulating levels of activin A in preeclampsia are closely correlated (Manuelpillai et al. 2001) and that circulating activin A levels fall very quickly after birth (Fowler et al. 1998). These observations are consistent with the placenta being the major source of circulating activin A in both normal pregnancy and preeclampsia. Nonetheless, in this study, we have also confirmed previous reports that endothelial cells produce activin A (Manuelpillai et al. 2001, Tannetta et al.
A
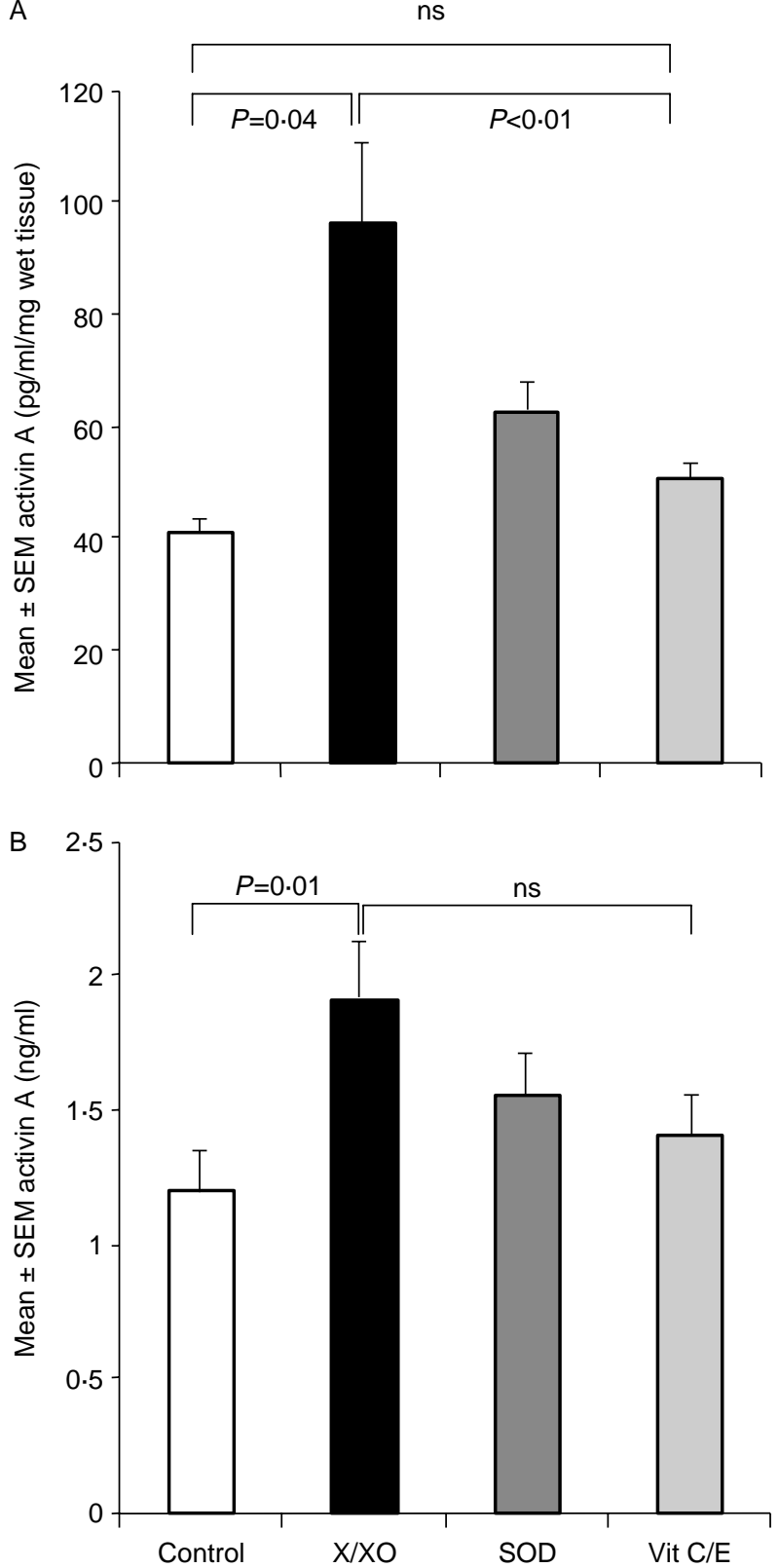

Figure 5 The effect of $X / X O$ and antioxidants (SOD and vitamin $C / E$ ) on activin secretion from placental explants (A) and HUVECs (B) in vitro at $24 \mathrm{~h}$. ns, not significant.

2003), suggesting that the endothelium may be another source of circulating activin A in preeclampsia. In contrast, while we were also able to confirm that monocytes produce activin A in vitro (Tannetta et al. 2003) our data suggest that these cells produce very little activin and that they do not respond to oxidative stress. Accordingly, we believe that circulating monocytes are not likely to be a major source of high activin A levels in women in preeclampsia. Further, if monocyte production of activin is increased in preeclampsia 
(Tannetta et al. 2003), then the mechanism underlying this is most likely via inflammatory cytokines (Tannetta et al. 2003) and not increased oxidative stress.

Whatever the relative contributions of the placenta and the endothelium to circulating activin, until now the mechanism(s) underlying the heightened levels of activin observed in preeclampsia have been obscure. Here, we have shown that oxidative stress, induced by $\mathrm{X} / \mathrm{XO}$, significantly increases the production and secretion of activin $\mathrm{A}$ from both placental explants and endothelial cells in vitro. We chose $\mathrm{X} / \mathrm{XO}$ to induce oxidative stress as this is thought to be one of the mechanisms underlying ischaemia-reperfusion injury in the placenta in preeclampsia (Hung et al. 2001). The addition of $\mathrm{X} / \mathrm{XO}$ results in the increased production of $\mathrm{O}_{2}^{-}$in the first instance and thereafter peroxidative damage. The mitigation of this effect by the antioxidants vitamin $\mathrm{C}$ and $\mathrm{E}$ confirms that oxidative stress was involved although precisely which reactive oxygen species are acting to increase activin has not been explored completely. That SOD did not mitigate the effects of $\mathrm{X} / \mathrm{XO}$ was surprising, as SOD exerts its antioxidant effects via scavenging $\mathrm{O}_{2}^{-}$. It is possible that $\mathrm{X} / \mathrm{XO}$-induced lipid peroxidation, mitigated by vitamin $\mathrm{C} / \mathrm{E}$ but not SOD, may have led to increased activin, but further studies are required to precisely define which reactive oxygen species are involved.

It is also unclear whether oxidative stress increases activin directly or indirectly in vitro. In this regard, oxidative stress is known to activate the transcription factor NF- $\kappa \mathrm{B}$, which in turn induces a number of pro-inflammatory cytokines (Li \& Karin 1999). This is relevant because activin release from a number of cell types, including trophoblast cells, is stimulated by inflammation (Keelan et al. 2000, Jones et al. 2004). Indeed, recent ovine studies have suggested that, together with TNF- $\alpha$, activin release is one of the very first responses to systemic inflammation significantly preceding elevations in other inflammatory cytokines such as interleukin-6 (Jones et al. 2004). Thus, in the context of preeclampsia, which is essentially an exaggerated systemic inflammatory disease (Sibai et al. 2005) triggered, at least in part, by oxidative placental damage (Hubel 1999, Burton \& Jauniaux 2004, Myatt \& Cui 2004), it is very likely that excessive placental and/or endothelial oxidative stress, induced inflammation leads to increased activin production (Manuelpillai et al. 2001, Silver et al. 2002). Further studies are required to define, whether the effects of oxidative stress on activin transcription and production are NF- $\kappa \mathrm{B}-$ dependent.

It is possible that the control condition of $20 \% \mathrm{O}_{2}$, used in this study, which is physiologically hyperoxic, in itself increased activin output through relative oxidative stress. Indeed, previous in vitro studies using placental explants have shown that reduced $\mathrm{O}_{2}$ reduces activin production (Blumenstein et al. 2002, Manuelpillai et al. 2003). In those studies activin output from placental explants in a 'low' oxygen environment was compared with output in air $\left(20 \% \mathrm{O}_{2}\right)$. The findings of this current study suggest that rather than 'low' oxygen reducing placental activin secretion, the control conditions of $20 \% \mathrm{O}_{2}$, which is physiologically hyperoxic, is likely to have artificially increased activin output through relative oxidative stress. In light of this current study, it would be worthwhile revisiting the previous work with supplemental antioxidants in the culture media. This would be expected to assist with understanding the relative roles of early placental hypoxia-hyperoxia in the pathogenesis of preeclampsia (Hubel 1999). With regard to the current study, it is possible that culture of trophoblast in $20 \% \mathrm{O}_{2}$, itself induces oxidative stress prior to treatment with $\mathrm{X} / \mathrm{XO}$ or at least augments the effect of $\mathrm{X} / \mathrm{XO}$ due to the increased availability of $\mathrm{O}_{2}$, which is needed to generate $\mathrm{O}_{2}^{-}$. In this regard, as with any in vitro culture data, care should be taken when extrapolating these in vitro findings to in vivo mechanisms.

Nonetheless, the observation here that circulating levels of activin A and 8-isoprostane were strongly correlated in women with preeclampsia, but not in women with a normal pregnancy, is consistent with our interpretation of the in vitro data that oxidative stress is the mechanism leading to increased activin secretion. Eight-isoprostane is thought to be a sensitive and stable marker of oxidative stress, derived from cell membrane phospholipids by free radical peroxidation of arachidonic acid (Morrow \& Roberts 1996, Roberts \& Morrow 2000). Circulating levels of 8-isoprostane are increased in preeclampsia (McKinney et al. 2000). The apparent relationship between activin and isoprostane suggests that in any given individual the circulating level of activin A may reflect the severity of systemic oxidative damage, offering the potential use of activin as a marker of disease progression and/or response to therapy. Of course, in this current study we have not assessed whether the treatment of preeclampsia alters activin A levels, but the recent report that antioxidant treatment suppresses oxidative stress and the subsequent inflammatory response in placental explants suggests that this would be worthy of study (Cindrova-Davis et al. 2006). Further, in women who subsequently develop preeclampsia circulating activin A levels increase in early pregnancy, long before clinical signs or symptoms (Muttukrishna et al. 2000). This early increase in activin may be indicative of early placental oxidative damage affording further insights into the timing and progress of the pathogenesis of preeclampsia.

In summary, we have shown that oxidative stress is a possible mechanism underlying increased activin A production from the placenta and/or endothelium in preeclampsia and that activin may be a useful marker of systemic oxidative damage.

\section{Acknowledgements}

E M W has a NHMRC (Australia) Clinical Career Development Award. This work was funded by a NHMRC (Australia) Program Grant \#334011. The authors declare that there is no conflict of interest that would prejudice the impartiality of this scientific work. 


\section{References}

Barkehall-Thomas A, Tong S, Baker LS, Edwards A \& Wallace EM 2006 Maternal serum activin A and the prediction of intrauterine growth restriction. Australian and New Zealand Journal of Obstetrics and Gynaecology 46 97-101.

Blumenstein M, Mitchell MD, Groome NP \& Keelan JA 2002 Hypoxia inhibits activin A production by term villous trophoblast in vitro. Placenta 23 735-741.

Bobrow CS, Holmes RP \& Muttukrishna S 2002 Maternal serum activin A, inhibin $\mathrm{A}$, and follistatin in pregnancies with appropriately grown and small-for-gestational-age fetuses classified by umbilical artery Doppler ultrasound. American Journal of Obstetrics and Gynecology 86 283-287.

Brosens I \& Renaer M 1972 On the pathogenesis of placental infarcts in preeclampsia. Journal of Obstetrics and Gynaecology of the British Commonwealth 79 794-799.

Brown MA, Hague WM, Higgins J, Lowe S, McCowan L, Oats J, Peek MJ, Rowan JA \& Walters BN 2000 The detection, investigation and management of hypertension in pregnancy: full consensus statement. Australian and New Zealand Journal of Obstetrics and Gynaecology 40 139-155.

Burton GJ \& Hung TH 2003 Hypoxia-reoxygenation; a potential source of placental oxidative stress in normal pregnancy and preeclampsia. Fetal and Maternal Medicine Reviews 14 97-117.

Burton GJ \& Jauniaux E 2004 Placental oxidative stress: from miscarriage to preeclampsia. Journal of the Society for Gynecologic Investigation 11 342-352.

Cindrova-Davis T, Spasic-Boskovic O, Jauniaux E, Charnock-Jones DS \& Burton GJ 2006 Vitamin C and E suppress oxidative stress, secretion of inflammatory cytokines and soluble VEGFR1, induction of vascular adhesion molecules and apoptosis in human placental explants. Journal of the Society for Gynecologic Investigation 13 287A.

D'Antona D, Reis FM, Benedetto C, Evans LW, Groome NP, de Kretser DM, Wallace EM \& Petraglia F 2000 Increased maternal serum activin A but not follistatin levels in pregnant women with hypertensive disorders. Journal of Endocrinology 165 157-162.

de Kretser DM, Foulds LM, Hancock M \& Robertson DM 1994 Partial characterization of inhibin, activin, and follistatin in the term human placenta. Journal of Clinical Endocrinology and Metabolism 79 502-507.

Fowler PA, Evans LW, Groome NP, Templeton A \& Knight PG 1998 A longitudinal study of maternal serum inhibin-A, inhibin-B, activin-A, activin- $\mathrm{AB}$, pro-alphaC and follistatin during pregnancy. Human Reproduction 13 3530-3536.

Hafsi N, Voland P, Schwendy S, Rad R, Reindi W, Gerhard M \& Prinz C 2004 Human dendritic cells respond to Helicobacter pylori, promoting NK cell and Th1-effector responses in vitro. Journal of Immunology 173 1249-1257.

Hubel CA 1999 Oxidative stress in the pathogenesis of preeclampsia. Proceedings of the Society for Experimental Biology and Medicine 222 222-235.

Hung TH, Skepper JN \& Burton GJ 2001 In vitro ischemia-reperfusion injury in term human placenta as a model for oxidative stress in pathological pregnancies. American Journal of Pathology 159 1031-1043.

Hung TH, Charnock-Jones DS, Skepper JN \& Burton GJ 2004 Secretion of tumor necrosis factor-alpha from human placental tissues induced by hypoxia-reoxygenation causes endothelial cell activation in vitro: a potential mediator of the inflammatory response in preeclampsia. American Journal of Pathology 164 1049-1061.

Jaffe EA, Nachman RL, Becker CG \& Minick CR 1973 Culture of human endothelial cells derived from umbilical veins. Identification by morphologic and immunologic criteria. Journal of Clinical Investigation $\mathbf{5 2}$ 2745-2756.

Jenkin G, Ward J, Hooper S, O'Connor A, de Kretser D \& Wallace E 2001 Feto-placental hypoxemia regulates the release of fetal activin A and prostaglandin E2. Endocrinology 142 963-966.

Jones KL, David M, de Kretser DM, Patella S \& Phillips DJ 2004 Activin A and follistatin in systemic inflammation. Molecular and Cellular Endocrinology $225119-125$
Keelan JA, Zhou RL, Evans LW, Groome NP \& Mitchell MD 2000 Regulation of activin A, inhibin A, and follistatin production in human amnion and choriodecidual explants by inflammatory mediators. Journal of the Society for Gynecologic Investigation 7 291-296.

Khullar S, Greenwood SL, McCord N, Glazier JD \& Ayuk PT 2004 Nitric oxide and superoxide impair human placental amino acid uptake and increase $\mathrm{Na}+$ permeability: implications for fetal growth. Free Radical Biology and Medicine 36 271-277.

Li N \& Karin M 1999 Is NF-kappaB the sensor of oxidative stress? FASEB Journal 13 1137-1143.

Malek A, Sager R \& Schneider H 2001 Effect of hypoxia, oxidative stress and lipopolysaccharides on the release of prostaglandins and cytokines from human term placental explants. Placenta 22(Suppl A) S45-S50.

Manuelpillai U, Schneider-Kolsky M, Dole A \& Wallace EM 2001 Activin A and activin receptors in gestational tissue from preeclamptic pregnancies. Journal of Endocrinology 171 57-64.

Manuelpillai U, Schneider-Kolsky M, Thirunavukarasu P, Dole A, Waldron K \& Wallace EM 2003 Effect of hypoxia on placental activin A, inhibin A and follistatin synthesis. Placenta 24 77-83.

Massague J 1990 The transforming growth factor-beta family. Annual Review of Cell Biology 6 597-641.

Matthiesen L, Berg G, Ernerudh J, Ekerfelt C, Jonsson Y \& Sharma S 2005 Immunology of preeclampsia. Chemical Immunology and Allergy 89 49-61.

McKinney ET, Shouri R, Hunt RS, Ahokas RA \& Sibai BM 2000 Plasma, urinary, and salivary 8 -epi-prostaglandin f2alpha levels in normotensive and preeclamptic pregnancies. American Journal of Obstetrics and Gynecology 183 874-877.

Milczarek R, Klimek J \& Zelewski L 2000 The effects of ascorbate and alphatocopherol on the NADPH-dependent lipid peroxidation in human placental mitochondria. Molecular and Cellular Biochemistry 210 65-73.

Morrow JD \& Roberts LJ 1996 The isoprostanes. Current knowledge and directions for future research. Biochemical Pharmacology 51 1-9.

Muttukrishna S, Fowler PA, George L, Groome NP \& Knight PG 1996 Changes in peripheral serum levels of total activin A during the human menstrual cycle and pregnancy. Journal of Clinical Endocrinology and Metabolism 81 3328-3334.

Muttukrishna S, Knight PG, Groome NP, Redman CW \& Ledger WL 1997 Activin A and inhibin A as possible endocrine markers for pre-eclampsia. Lancet 349 1285-1288.

Muttukrishna S, North RA, Morris J, Schellenberg JC, Taylor RS, Asselin J, Ledger W, Groome N \& Redman CW 2000 Serum inhibin A and activin A are elevated prior to the onset of pre-eclampsia. Human Reproduction $\mathbf{1 5}$ 1640-1645.

Myatt L \& Cui X 2004 Oxidative stress in the placenta. Histochemistry and Cell Biology 122 369-382.

Perkins A 2006 Endogenous anti-oxidants in pregnancy and preeclampsia. Australian and New Zealand Journal of Obstetrics and Gynaecology 46 77-83.

Qu J \& Thomas K 1995 Inhibin and activin production in human placenta. Endocrine Reviews 16 485-507.

Redman CW \& Sargent IL 2000 Placental debris, oxidative stress and preeclampsia. Placenta 21 597-602.

Riley SC, Balfour C, Wathen NC, Chard T, Evans LW, Groome NP \& Wallace EM 1998 Follistatin and activin A in extra-embryonic coelomic and amniotic fluids and maternal serum in early pregnancy. Human Reproduction 13 2624-2628.

Roberts JM \& Hubel CA 1999 Is oxidative stress the link in the two-stage model of pre-eclampsia? Lancet 354 788-789.

Roberts LJ \& Morrow JD 2000 Measurement of F(2)-isoprostanes as an index of oxidative stress in vivo. Free Radical Biology and Medicine 28 505-513.

Schneider-Kolsky ME, Manuelpillai U, Waldron K, Dole A \& Wallace EM 2002 The distribution of activin and activin receptors in gestational tissues across human pregnancy and during labour. Placenta 23 294-302.

Sibai B, Dekker G \& Kupferminc M 2005 Preeclampsia. Lancet 365 785-799. Silver HM, Lambert-Messerlian GM, Reis FM, Diblasio AM, Petraglia F \& Canick JA 2002 Mechanism of increased maternal serum total activin A and inhibin A in preeclampsia. Journal of the Society for Gynecologic Investigation 9 308-312. 
Soleymanlou N, Jurisica I, Nevo O, Ietta F, Zhang X, Zamudio S, Post M \& Caniggia I 2005 Molecular evidence of placental hypoxia in preeclampsia. Journal of Clinical Endocrinology and Metabolism 90 4299-4308.

Supramaniam VG, Jenkin G, Loose J, Wallace EM \& Miller SL 2006 Chronic fetoplacental hypoxia increases activin A secretion in the late-pregnant sheep. BJOG: an International Journal of Obstetrics and Gynaecology 113 102-109.

Tannetta DS, Muttukrishna S, Groome NP, Redman CW \& Sargent IL 2003 Endothelial cells and peripheral blood mononuclear cells are a potential source of extraplacental activin A in preeclampsia. Journal of Clinical Endocrinology and Metabolism 88 5995-6001.

Tong S, Wallace EM \& Burger HG 2003 Inhibins and activins: advances in reproductive medicine. Clinical Endocrinology 58 115-127.

Wallace EM \& Healy DL 1996 Inhibins and activins: roles in clinical practice. British Journal of Obstetrics and Gynaecology 103 945-956.
Wallace EM, Schneider-Kolsky ME, Edwards A, Baker L \& Jenkin G 2003 Maternal serum activin A levels in association with intrauterine fetal growth restriction. BJOG: an International Journal of Obstetrics and Gynaecology 110 306-310.

Walsh SW 1998 Maternal-placental interactions of oxidative stress and antioxidants in preeclampsia. Seminars in Reproductive Endocrinology 16 93-104.

Received in final form 3 December 2006

Accepted 6 December 2006

Made available online as an Accepted Preprint 28 December 2006 